\title{
Evaluation of trace elements and oxidative stress levels in the liver and kidney of streptozotocin-induced experimental diabetic rat model
}

\author{
Dervis Ozcelik ${ }^{1}$, Matem Tuncdemir ${ }^{2}$, Melek Ozturk ${ }^{2}$ and Hafize Uzun ${ }^{3}$ \\ ${ }^{1}$ Department of Biophysics, Cerrahpasa Medical Faculty, Istanbul University, Istanbul, Turkey \\ ${ }^{2}$ Department of Medical Biology, Cerrahpasa Medical Faculty, Istanbul University, Istanbul, Turkey \\ ${ }^{3}$ Department of Biochemistry, Cerrahpasa Medical Faculty, Istanbul University, Istanbul, Turkey
}

\begin{abstract}
In this study, we aimed to investage the relationship among trace elements $(\mathrm{Cu}, \mathrm{Fe}, \mathrm{Zn}$ and $\mathrm{Mg}$ ) on oxidative and anti-oxidative substances in liver and kidneys tissues in streptozotocin (STZ) diabetic rat model. The mean levels of $\mathrm{Fe}$ and $\mathrm{Cu}$ were found significantly higher in the liver and kidneys of the diabetic rats, in comparison to the control rats. On the other hand, the mean levels of $\mathrm{Zn}$ and $\mathrm{Mg}$ in the liver and kidneys of the diabetic rats were significantly lower than in the control rats.

The liver and kidneys malonaldehyde (MDA) levels of the experimental group were found to be higher than in the control group ( $p<0.001 ; p<0.01$, respectively) after 4 weeks of the experimental period. Superoxide dismutase (SOD) activities and glutathione (GSH) levels in the liver tissue of STZ-induced diabetic rats were found to be lower in the experimental group than in the control group $(p<0.01)$. SOD activity and GSH concentration in kidneys of the diabetic rats were significantly diminished with respect to the control group $(p<0.01)$. In conclusion, the present results indicate that the increase of $\mathrm{Fe}$ and $\mathrm{Cu}$ together with decreas of $\mathrm{Zn}$ and $\mathrm{Mg}$ concentration in liver and kidney of STZ-induced diabetic rats may be involved in disturbances of oxidative balance in both the tissues. Therefore, these findings may contribute to explain the role of impaired ion metabolism of some elements in the progression of diabetic oxidative complications.
\end{abstract}

Key words: Trace element - STZ-diabetic rat - Oxidative stress - Liver - Kidney

\section{Introduction}

Diabetes-related dysfunctions are the major causes of mortality and morbidity for diabetic patients. Although the precise mechanism by which hyperglycemia induces organ dysfunction is not fully understood, one of the hypothesis to explain this phenomenon is mainly focused on the role of free radicals in disease. Free radicals are continually produced in the body as a result of normal metabolic processes and interaction with environmental stimuli. Under physiological conditions, a wide range of antioxidant defense mechanisms protect against the adverse effects of free radical production in vivo (Baynes 1991; Halliwell and Gutteridge 1999). Oxidative stress results from an imbal-

Correspondence to: Dervis Ozcelik, Department of Biophysics, Cerrahpasa Medical Faculty, Istanbul University, TR-34303, Cerrahpasa, Istanbul, Turkey

E-mail: dozcelik@istanbul.edu.tr ance between radical-generating and radical-scavenging systems, i.e. increased free radical production or reduced activity of antioxidant defense mechanism or both these phenomena. Oxidative stress is currently suggested as mechanism underlying diabetes and diabetic complications. Several studies have confirmed that hyperglycemia plays a key role in inducing oxidative stress in diabetes mellitus (Muchová et al.1999; Forbes et al. 2008). Diabetes is associated with the generation of reactive oxygen species (ROS), causing oxidative damage particularly to various tissues (Mohamed et al.1999). Glucose level was found to increase the production of free radicals, as determined by cell damage markers such as malonaldehyde (MDA) and conjugated dienes (Cuncio et al. 1995). Hyperglycemia can cause oxidative stress, which in turn may result in cellular tissue damage. The harmful influence of diabetes on metabolism of tissues and organs is well known. Likewise, uncontrolled hyperglycemia can lead to disturbances in the structure and functions of organs (Gupta et al. 2004). 
A number of evidence suggest that hyperglycemia might have adverse effects on many biochemical pathways like glucose oxidation, the formation of advanced glycation end-products (AGE), and activation of polyol pathways, which are related to generation of ROS and result in high level of oxidative stress in many tissues. However, it is not completely understood how hyperglycemia leads to increase in oxidative stress (Wang et al. 2006; Zheng et al. 2008; Wei et al. 2009). The contribution of other factors, including the alternations in the homeostasis ions of some trace and transition elements as $\mathrm{Fe}$ and $\mathrm{Cu}$ on the occurrence and progression of the disease is still being discussed in literature (Eaton and Qian 2002; Viktorínová et al. 2009). In the presence of certain metals (particularly iron or copper ions), a hydroxyl radical, which is the most powerful ROS, can be produced via the Fenton or the metal-catalyzed HaberWeiss reaction (Repetto et al. 2010). These two chemical reactions appear to account for most of the hydroxyl radical production in biological systems and explain, at least in part, why metals such as $\mathrm{Fe}$ and $\mathrm{Cu}$ produce oxidative stress and ROS-induced injury in cells. Tissue accumulation of transition metals ions is extremely toxic, leading to many pathologic conditions consistent with oxidative damage to biologic membranes and molecules (Halliwell and Gutteridge 1999; Ozcelik and Uzun 2009). Transition metal ions strongly bind to phospholipids and alter the liposome bilayer and increase their susceptibility to lipid peroxidation (Oteiza et al. 2004). Both the essentiality and toxicity of these metals ions in the pathogenesis of diabetes mellitus and diabetic complications are often reported (Walter et al. 1991; Aguilar et al. 2007; Zheng et al. 2008). Transition metals ions also play a role in protein glycation induced by hyperglycemia. It has been shown that glycated proteins have a substantial affinity for the transition metals, and the bound metal retains redox activity and participates in catalytic oxidation (Qian et al. 1998). Although the toxicity of transition metals is well known at present; however, the mechanism behind their toxicity is still obscure in diabetes and diabetic complications. On these grounds, alterations in the tissue ion concentrations of several trace and transition elements might be responsible for oxidative stress in kidney and liver in diabetes mellitus.

Thus, the present study aims to investigate the effects of empirically created diabetes on element concentrations in liver and kidney tissues as well as on the formation of lipid peroxidation and antioxidant enzymes. For this purpose, it was aimed to evaluate lipid peroxidation status and antioxidative systems in normal and streptozotocin (STZ)-induced diabetic rats by measuring ion concentrations of $\mathrm{Zn}, \mathrm{Cu}, \mathrm{Fe}$ and $\mathrm{Mg}$ and MDA levels as well as the activity of antioxidant enzymes, superoxide dismutase (SOD) and non-enzymatic antioxidant glutathione (GSH) levels in kidney and liver tissues of the rats.

\section{Materials and Methods}

\section{Animals and protocols}

In the present study, Male Wistar albino rats weighing 210-230 g that obtained from the University of Istanbul Animal Research Laboratory were used. The rats were kept in the same unit and fed chow (Eris Chow Industry, Istanbul, Turkey) ad libitum. All rats had free access to tap water. All animals received humane care in compliance with the National Institutes of Health criteria for care of laboratory animals. The rats were divided into two groups - the control group (consisted by the non-diabetic rats) and group consisted of diabetic rats. Diabetes was induced by a single dose intraperitoneally (i.p.) injection of STZ (Sigma, St. Louis, MO, USA; $60 \mathrm{mg} / \mathrm{kg}$, single dose, i.p.). On the 2nd day following STZ injection, blood glucose levels were measured and rats with blood glucose at least threefold of the pre-injection levels were used as diabetics group in our experiments. At the beginning of the study, blood glucose levels and body weights of all rats were measured. Experiments were carried out over 4 weeks and were started 3 days after STZ injection.

At the 1st and 28th day of the experiment, all rats from each group were housed in metabolic cages in order to collect 24-h urine samples. All rats were sacrificed at the end of 4 th week under ether anesthesia. After decapitation, the kidney and liver tissues were quickly excised and stored at $-70^{\circ} \mathrm{C}$ for further experiments.

\section{Blood glucose}

At the 1st and 28th day of the experiment, blood glucose levels of all groups were measured using reagent strips (Accu-Check Active Glucose test strips, Roche, Germany) with a glucometer (Accu-Check Active, Roche, Germany) in samples obtained from the tail vein.

\section{Tissue homogenization}

Liver and kidney samples were weighed, washed in $0.9 \%$ $\mathrm{NaCl}$, and homogenized in $0.15 \mathrm{M} 10 \% \mathrm{KCl}(\mathrm{w} / \mathrm{v})$, for lipid peroxidation parameters and for the other studies after they were melted. Homogenates of $20 \%$ were obtained and sonicated two times at $30-\mathrm{sec}$ intervals at $4^{\circ} \mathrm{C}$. After sonication, homogenates for lipid peroxidation and biochemical studies were centrifuged at $500 \times g$ for $10 \mathrm{~min}$ and at $12,500 \times g$ for $15 \mathrm{~min}$, respectively. Aliquots of the supernatants were used for both studies. The assayed parameters were expressed per milligram of protein. The protein content of the aliquots was determined on the $\mathrm{HCl}$ blank pellets spectrophotometrically using a Folin kit (Sigma Diagnostics, St.Louis, MO, USA) by the method of Lowry et al. (1951). 


\section{Lipid peroxidation}

Lipid peroxidation was ascertained by the formation of MDA as an end product of fatty acid peroxidation. MDA levels were measured in tissue homogenates by the thiobarbituric acid reactivity assay as previously described (Angel et al. 1998). Thiobarbituric acid-reactive substances (TBARS) concentration was calculated using $1.56 \times 10^{-5}$ $\mathrm{M}^{-1} \cdot \mathrm{cm}^{-1}$ as molar extinction coefficient. Tissue MDA levels were expressed as nanomoles per milligram of protein.

\section{Superoxide dismutase level}

$\mathrm{Cu}-\mathrm{Zn}$-superoxide dismutase (Cu-Zn-SOD) activity was determined by the method of Sun et al. (1988). The assay involves inhibition of nitroblue tetrazolium (NBT) (Sigma Co., St. Louis, USA) and reduction with xanthine-xanthine oxidase (Sigma Co., St. Louise, USA) that was used as a superoxide generator. One unit of SOD is defined as the amount of protein that inhibits the rate of NBT reduction by $50 \%$. Tissue SOD activities were expressed as units per milligram of protein.

\section{Glutathione level}

Tissue GSH concentrations were determined according to the method of Beutler et al. (1963) using metaphosphoric acid for protein precipitation and 5',5' -dithiobis(2-nitrobenzoic acid) for color development. GSH concentration was calculated using $1.36 \times 10^{4} \mathrm{M}^{-1} \cdot \mathrm{cm}^{-1}$ as the molar absorption coefficient. Tissue GSH concentrations were expressed as $\mu \mathrm{mol}$ per gram of protein.

Biochemical studies were performed using an autoanalyser (Hitachi 717).

\section{The tissue element analysis}

Approximately $0.5-1 \mathrm{~g}$ of tissue was obtained from each animal for this purpose. After wet-ashing of tissues with nitric and perchloric acid, the liver and kidney tissue $\mathrm{Zn}, \mathrm{Cu}, \mathrm{Fe}$ and $\mathrm{Mg}$ levels were studied by atomic absorption spectro- photometry (Shimadzu AA-680, Japan) with an air-acetylene flame. The tissue concentrations of element are expressed as micrograms per gram of wet weight (Clegg et al. 1981).

\section{Urine collection and metal analysis}

Urine samples from control rats and STZ-diabetic rats were collected during experiments.

All rats from each group were housed in metal-free metabolic cages in order to collect 24 -h urine samples. The urine volumes were measured, and samples were centrifuged at $3000 \times g$ for 10 minutes to remove bacteria, cells, casts and other particulate materials. Urine samples were stored at $-20^{\circ} \mathrm{C}$. The levels of $\mathrm{Zn}, \mathrm{Cu}$ and $\mathrm{Mg}$ in urine were measured by atomic absorption spectrophotometry (Shimadzu AA680, Japan) with an air-acetylene flame.

\section{Statistical analysis}

All results are expressed as mean \pm standard deviation. Comparisons between the groups were performed by the Mann-Whitney U-test and a $p<0.05$ was accepted as statistically significant.

\section{Results}

\section{General characteristics of experimental animals}

After two days following STZ injection the rats showed a significant increase $(p<0.01)$ in blood glucose levels, as expected. After four weeks following STZ injection, diabetes also caused a significant reduction $(p<0.05)$ in body weight compared to control animals. In STZ-induced diabetes, the daily urine output levels were measured significantly higher $(p<0.01)$ than the non-diabetic rats (Table 1).

\section{Total concentrations of elements in organs of diabetic and control rats}

The comparison of concentrations $\mathrm{Cu}, \mathrm{Fe}, \mathrm{Mg}$ and $\mathrm{Zn}$ in the liver, kidney and urine of the STZ-diabetic and

Table 1. General characteristic of the experimental animals

\begin{tabular}{lllcc}
\hline Groups & & Body weight $(\mathrm{g})$ & Blood glucose $(\mathrm{mg} / \mathrm{dl})$ & Urine output $(\mathrm{ml})$ \\
\hline \multirow{2}{*}{ Control $(n=7)$} & start & $209.88 \pm 8.32$ & $91.00 \pm 1.69$ & $13.88 \pm 3.44$ \\
& end & $228.50 \pm 19.03$ & $93.37 \pm 2.77$ & $16.00 \pm 1.07$ \\
\cline { 2 - 3 }$(n=8)$ & start & $211.38 \pm 11.31$ & $393.25 \pm 15.29^{* *}$ & $15.25 \pm 2.12$ \\
& end & $182.50 \pm 25.55^{*}$ & $426.75 \pm 73.14^{* *}$ & $47.38 \pm 3.11^{* *}$ \\
\hline
\end{tabular}

Start, the beginnig of the experiment; end, the end of the experiment. Values were given as mean \pm SD. ${ }^{*} p<0.05$; ${ }^{* *} p<0.01 v s$. control group animals. 
the control rats after four weeks following STZ injection are presented in Figure 1. The mean levels of $\mathrm{Fe}$ and $\mathrm{Cu}$ in the liver of the diabetic rats were significantly higher $(p<0.05)$ than in the control rats. On the other hand, the mean levels of $\mathrm{Zn}$ and $\mathrm{Mg}$ were significantly lower $(p<$ 0.01 ) in the liver of the diabetic rats, in comparison to the control rats. In kidney, the $\mathrm{Fe}$ and $\mathrm{Cu}$ concentration in the diabetic rats was significantly higher than in the control rats $(p<0.05, p<0.01$, respectively) whereas for $\mathrm{Mg}$ and $\mathrm{Zn}$, their concentrations in the diabetic rats were statistically lower $(p<0.01)$ than in the controls. Analysis of the effect of STZ-induced diabetes revealed that the $\mathrm{Zn}$ and $\mathrm{Mg}$ concentration significantly increased in the daily urine output of the diabetic rats $(p<0.01$ and $p<$ 0.001 , respectively), while the concentrations of $\mathrm{Cu}$ in the diabetics were slightly lower $(p<0.05)$ than in the control rats (Figure 1).
SOD activity and GSH and MDA levels of the liver and kidney

SOD activity and GSH and MDA levels of experimental and control groups obtained from the measurement of related tissues are given in Table 2. The liver MDA levels of the experimental group were found to be higher than in the control group $(p<0.001)$. SOD activities in the liver tissue of STZ-induced diabetic rats were lower than in that of the control group $(p<0.01)$. Liver GSH levels were found to be lower in the experimental group than in the control group $(p<0.01)$. The MDA content of the kidneys of STZ-induced diabetic rats was significantly higher than in the control rats after 4 week of the experimental period $(p<0.01)$. SOD activity in kidney of the diabetic rats were significantly diminished with respect to the control group $(p<0.01)$. In kidney, the measured GSH concentration
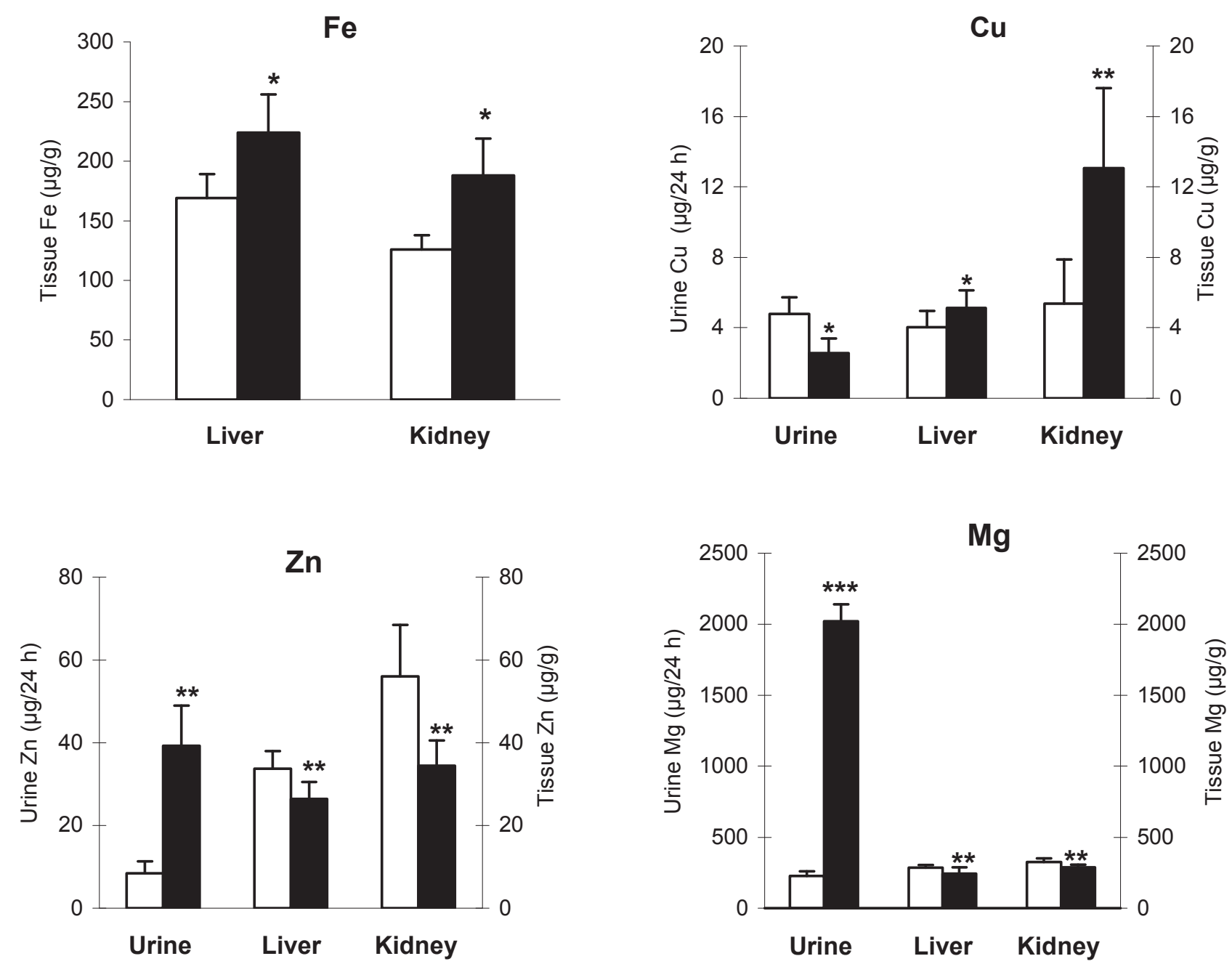

Figure 1. Comparison of liver, kidney and urine concentrations of $\mathrm{Cu}, \mathrm{Zn}, \mathrm{Fe}$ and $\mathrm{Mg}$ in control and STZ-diabetic rats. $\square$ control group, - STZ-diabetic group. ${ }^{*} p<0.05,{ }^{* *} p<0.01,{ }^{* * *} p<0.001$ vs. control group animals. 
Table 2. Comparison of kidney and liver tissue levels of MDA, SOD, and GSH in control and diabetic rats

\begin{tabular}{llccc}
\hline \multirow{2}{*}{ Tissue } & & $\begin{array}{c}\text { MDA } \\
(\mathrm{nmol} / \mathrm{mg} \text { of protein })\end{array}$ & $\begin{array}{c}\text { GSH } \\
(\mu \mathrm{mol} / \mathrm{mg} \text { of protein })\end{array}$ & $\begin{array}{c}\text { SOD } \\
(\mathrm{U} / \mathrm{mg} \text { of protein })\end{array}$ \\
\hline \multirow{2}{*}{ Liver } & Control & $1.020 \pm 0.126$ & $80.01 \pm 8.73$ & $170.57 \pm 10,46$ \\
& Diabetic & $1.605 \pm 0.122^{* *}$ & $67.41 \pm 5.69^{*}$ & $110.14 \pm 13.76^{*}$ \\
\cline { 2 - 5 } Kidney & Control & $0.213 \pm 0.029$ & $116.74 \pm 13.94$ & $1.51 \pm 0.08$ \\
& Diabetic & $0.538 \pm 0.057^{*}$ & $94.47 \pm 8.57^{*}$ & $1.41 \pm 0.03^{*}$ \\
\hline
\end{tabular}

Values were given as mean \pm SD. ${ }^{*} p<0.01,{ }^{* *} p<0.001 v s$. control group.

seems to significantly decrease with the induction of the diabetes $(p<0.01)$.

\section{Discussion}

In the present study, a significant increase was observed in blood glucose level in STZ-induced diabetic rats due to the destruction of pancreatic $\beta$ cells by STZ. On the other hand, a significant decrease was determined in body weight compared to those of control rats, and daily urine output levels were significantly higher than those of non-diabetic rats. These results are in accordance with the results previously reported after STZ treatment of diabetic rats (Lau and Failla 1984; Yanardag et al. 2003; Ravi et al. 2004).

There are many studies using experimental diabetic modeling and reporting increases in lipid peroxidation or changes in element metabolism in diabetic patients (Wilson et al. 2003; Song et al. 2005). Previous researchers have suggested an interrelationship between diabetes and various micronutrients, including $\mathrm{Mg}, \mathrm{Cr}, \mathrm{Fe}, \mathrm{Zn}, \mathrm{Cu}$, etc. Moreover, several studies have shown an increased lipid peroxidation in clinical and experimental diabetes (Niskanen et al. 1995; Kakar et al. 1998; Viktorínová et al. 2009). However, nearly of all these studies are separate studies demonstrating the effects of diabetes on oxidative stress or metabolism of some elements. The present study investigates the formation of oxidative stress in liver and kidney tissues and the changes in the ion concentrations of some elements in the same tissues with changing antioxidant levels by using an empirically formed diabetic rat modeling with a different approach. For this purpose, the role of diabetes on ion alterations of transition and trace metals ( $\mathrm{Fe}, \mathrm{Cu}, \mathrm{Zn}$ and $\mathrm{Mg}$ ) in liver and kidney tissues of STZ-diabetic rat were investigated in the present study. Besides, oxidative stress was assessed by measuring MDA concentration and the activity of antioxidant enzymes SOD and non-enzymatic antioxidant GSH levels in both tissues of STZ-induced diabetic rats. In the experimental study model, resulting induction of diabetes clearly demonstrated that impaired ion metabolism of trace elements is observed in liver and kidney tissues of STZ-diabetic rats.
In the present study, the concentrations of $\mathrm{Cu}$ and $\mathrm{Fe}$ in liver and kidney of the diabetic rats were found significantly higher than in the control rats, while $\mathrm{Zn}$ and $\mathrm{Mg}$ concentrations were significantly lower in diabetic rats in comparison with all the observed tissues of the control rats. The levels of $\mathrm{Zn}$ and $\mathrm{Mg}$ were also found significantly higher, while the level of $\mathrm{Cu}$ was significantly lower in urinary excretion with STZ-diabetic rats. The results of the present study confirmed that urinary excretion of $\mathrm{Mg}$ and $\mathrm{Zn}$ is increased in diabetes as reported by Walter et al. (1991). In STZ-induced type 1 diabetic mice, a significant decrease was observed in hepatic Zn levels in diabetic mice at 1 or 3 months after hyperglycemia (Wang et al 2006). Cai et al. (2002), reported that the hepatic $\mathrm{Zn}, \mathrm{Cu}$, and Fe levels were significantly decreased in the diabetic rats at 6 months. In contrast, renal $\mathrm{Cu}$ and Fe levels were increased in diabetic rats with no change in renal $\mathrm{Zn}$ levels. Abou-seif and Youssef (2004) also found that hyperglycemia was associated with increased plasma levels of copper.

In conclusion, many studies in literature regarding the STZ-diabetic rats reported that the impaired absorption or the excess excretion of these metals in urine (glycosuria) could be effective on the impairment of homeostasis of these elements.

Impaired metabolism of trace elements is observed in diabetic patients. It has been reported that the urinary excretion of $\mathrm{Ca}, \mathrm{Zn}$ and $\mathrm{Mg}$ is increased in two types of diabetes mellitus, causing a decrease in blood levels of these elements from these patients (Cunningham et al. 1994; Brown et al. 1999). Another study reported that the levels of $\mathrm{Zn}$ and $\mathrm{Mg}$ were significantly lower, while the level of $\mathrm{Cu}$ was significantly higher in serum of patient with IDDM (insulin-dependent diabetes mellitus (Isbir et al. 1994). Failla and Kiser (1983) have reported that the concentration and the tissue contents of $\mathrm{Cu}$ in liver and kidney were significantly elevated by 1 week after STZ injection and increased thereafter, attaining two- and five-fold higher levels, respectively, than controls by 4 weeks.

In accordance with the findings of the present study, Dogukan et al. (2009) found that concentrations of $\mathrm{Zn}$ in liver and kidney of the diabetic rats were significantly lower than in the control rats. In contrast, higher $\mathrm{Fe}$ and $\mathrm{Cu}$ levels were found in tissues from diabetic versus the non-diabetic rats. The findings regarding the tissue contents of $\mathrm{Cu}$ in liver and 
kidney were also supported by Failla and Kiser (1981) who found that some trace metals accumulated in the organs of the diabetic rats. Raz and Havivi (1988) found that the levels of $\mathrm{Zn}$ and $\mathrm{Cu}$ in the liver of STZ-diabetic rats were significantly higher than the control animals, but the concentrations in the kidneys were similar of the diabetic and control rats. Although Johnson and Evans (1984) found that the concentrations of Fe in the liver and kidney of the STZ-diabetic rats were higher than in the control rats, contradictory results were obtained by Feng et al. (2001) who found lower Fe concentrations in both liver and kidney of STZ-diabetic rats.

There are certain differences among the studies in literature considering the changes in element concentrations in tissues; however, nearly all of these studies reported increases in $\mathrm{Fe}$ and $\mathrm{Cu}$ concentrations and decreases in $\mathrm{Zn}$ and $\mathrm{Mg}$ concentrations in kidney and liver tissues, which is compatible with the findings of the present study.

The results of the present study also indicated increases in MDA levels, product of increased lipid peroxidation in kidney and liver tissues of STZ-diabetic rats, and decreases in the activity of antioxidant enzyme SOD and non-enzymatic antioxidant GSH levels. These findings demonstrated that the oxidative balance in liver and kidney tissues of STZ-diabetic rats is impaired. The studies on diabetes patients and diabetic patient models reported that lipid peroxidation significantly increases in liver and kidney, which is compatible with the findings of the present study (Kakkar et al.1998; Obrosova et al. 2003). As indicated in the previous studies, free radical production is considered as one of the major mechanisms responsible for the toxicity of transition metals ions such as $\mathrm{Cu}$ and $\mathrm{Fe}$ (Repetto et al. 2010). Intake and excretion of Fe and $\mathrm{Cu}$, essential for organism, are required for a balanced organism. Excessive tissue accumulation of redox-active transition metals ions can be cytotoxic, in particular because perturbations in metal homeostasis result in an array of cellular disturbances characterized by oxidative stress and increased free radical production. They not only catalyze the formation of free-radical species that can start lipid peroxidation, but also the decomposition of previously formed lipid peroxides to spread lipid peroxidation (Parmar et al. 2002).

The findings of the studies demonstrated significantly higher increases in $\mathrm{Fe}$ and $\mathrm{Cu}$ concentrations in liver and kidney of diabetic rats as well as in MDA concentration, measured as an indicator of lipid peroxidation.

The transition metals $\mathrm{Fe}$ and $\mathrm{Cu}$ are integral parts of important enzymes involved in vital biologic processes. There are suggestive evidences that Fe plays a pathogenic role in diabetes and its complications such as microangiopathy and atherosclerosis. Diabetes mellitus is associated with altered Fe homeostasis in both human and animal diabetic models. Excess Fe has been implicated in the pathogenesis of diabetes and its complications (Thomas et al. 2004). The increased levels of $\mathrm{Cu}$, a transition metal that is a redox-active and catalyzes lipid peroxidation, may enhance oxidation of lowdensity lipoproteins (LDL), causing increased level of TBARS in diabetic patients as reported by Heinecke et al.(1984).

In the light of these findings, the accumulation of transition metals $\mathrm{Fe}$ and $\mathrm{Cu}$ in liver and kidney could play a catalytic role in increasing oxidative stress in these tissues.

In the present study, diabetes is also found associated with alterations in the oxidant defense system. This was shown by the lower GSH levels and SOD activity in the kidney and liver of the STZ-diabetic animals compared to the controls. The decrease in antioxidants may be due to the deficiency of tissue $\mathrm{Zn}$ and $\mathrm{Mg}$ in diabetic rats. These observations are supported by the findings that $\mathrm{Zn}$ and $\mathrm{Mg}$ have antioxidant activities because not only do they constitute the active sites and/or stabilize the conformation of several antioxidant enzymes, but they also compete for $\mathrm{Fe}$ - and $\mathrm{Cu}$-binding sites and can provide protection against transition metalmediated and free radical-induced injury (Alcock 1996). These findings are in agreement with the results of Wohaieb and Godin (1987) who found decreased SOD activity in the kidneys of rats with STZ-induced diabetes. Kawamura et al. (1992) found decreased SOD activity in erythrocytes of diabetic patients and ascribed it to glycation of the enzymatic protein, which led to a decrease in its activity. Similarly, Simonian et al. (1987) reported a decrease in the contents of $\mathrm{Cu}-\mathrm{Zn}-\mathrm{SOD}$ and catalase purified from rat liver at the terminal stages of alloxan-induced diabetes. Adachi et al. (1994) have reported that SOD levels were higher in the serum of patients with liver disease and diabetes than in normal subjects. GSH participates in the cellular defense system against oxidative stress by scavenging free radicals and reactive oxygen intermediates; in addition, its level is reduced in DM. Venkateswaran and Pari (2003) observed a significant decrease in GSH levels in liver tissue during diabetes and they suggested that the decrease in GSH levels represents the increased utilization due to oxidative stress. GSH also binds endogenous metals, such as $\mathrm{Cu}, \mathrm{Se}, \mathrm{Cr}$, and $\mathrm{Zn}$ via non-enzymatic reactions. GSH is one of the most versatile and pervasive metal-binding ligands and plays an important role in metal transport, storage, and metabolism. Thus, the decrease in GSH level might reflect a direct reaction between GSH and free radicals generated by hyperglycemia in diabetes (Yoshida et al. 1995).

In conclusion, the results of the present study indicate an imbalance in amounts of some elements including $\mathrm{Cu}, \mathrm{Fe}$, $\mathrm{Zn}$ and $\mathrm{Mg}$ in STZ-diabetic rats compared to their levels in healthy subjects. In addition, oxidative stress parameters like MDA level are found higher in liver and kidney tissues, while the activity of antioxidant enzyme SOD and non-enzymatic antioxidant GSH levels are reduced in these tissues. The disturbed oxidative balance in both tissues might be affected by the increases in Fe and $\mathrm{Cu}$ as well as the decreases in $\mathrm{Zn}$ and $\mathrm{Mg}$ levels in liver and kidney of STZ-induced diabetic 
rats. Therefore these findings may contribute to explain the role of impaired ion metabolism of some elements in the progression of diabetic oxidative complications.

\section{References}

Abou-Seif M. A. and Youssef A. (2004): Evaluation of some biochemical changes in diabetic patients. Clin. Chim. Acta 346, $161-170$ http://dx.doi.org/10.1016/j.cccn.2004.03.030

Adachi T., Nakamura M., Yamada H., Futenma A., Kato K., Hirano K. (1994): Quantitative and qualitative changes of extracellular superoxide dismutase in patients with various diseases. Clin. Chim. Acta 229, 129-131 http://dx.doi.org/10.1016/0009-8981(94)90234-8

Aguilar M. V., Saavedra P., Arrieta F. J., Mateos C. J., González M. J., Meseguer I., Martínez-Para M. C. (2007): Plasma mineral content in type- 2 diabetic patients and their association with metabolic syndrome. Ann. Nutr. Metab. 51, 402-406 http://dx.doi.org/10.1159/000108108

Alcock N. W. (1996): Trace elements. In: Clinical Chemistry, Theory, Analysis and Correlation. (Eds. A. L. Kahn and A. J. Pesce), pp. 746-759, Mosby-Year Book, St. Louis

Angel M. F., Ramasastry S. S., Swartz W. M., Narayanan K., Kuhns D. B., Basford R. E., Futrell J. W. (1988): The critical relationship between free radicals and degrees of ischemia: Evidence for tissue intolerance of marginal perfusion. Plast. Reconstr. Surg. 81, 233-259 http://dx.doi.org/10.1097/00006534-198802000-00017

Baynes J. W. (1991): Role of oxidative stress in development of complications in diabetes. Diabetes 40, 405-412 http://dx.doi.org/10.2337/diabetes.40.4.405

Beutler E., Durgn D., Kelly M. (1963): Improved method for the determination of blood glutathione. J. Lab. Clin. Med. 51, 882-888

Brown I. R., McBain A. M., Chalmers J., Campbell I. W., Brown E. R., Lewis M. J. (1999): Sex difference in the relationship of calcium and magnesium excretion to glycaemic control in type-1 diabetes mellitus. Clin. Chim. Acta 283, 119-128 http://dx.doi.org/10.1016/S0009-8981(99)00040-6

Cai L., Chen S., Evans T., Cherian M. G., Chakrabarti S. (2002): Endothelin-1-mediated alteration of metallothionein and trace metals in the liver and kidneys of chronically diabetic rats. Int. J. Exp. Diabetes Res. 3, 193-198 http://dx.doi.org/10.1080/15604280214281

Clegg M. S., Keen C. L., Lönnerdal B., Hurley L. S. (1981): Influence of ashing techniques in the analyses of trace elements in animal tissue. Biol. Trace Elem. Res. 3, 107-115 http://dx.doi.org/10.1007/BF02990451

Cunningham J. J., Fu A., Mearkle P. L., Brown R. G. (1994): Hyperzincurea in individuals with insulin-dependent diabetes mellitus: concurrent zinc status and the effect of high dose zinc supplementation. Metabolism 43, 1558-1562 http://dx.doi.org/10.1016/0026-0495(94)90016-7

Curcio F., Pegoraro I., Dello Russo P., Falleti F., Perrella G., Ceriello A. (1995): SOD and GSH inhibit the high glucoseinduced oxidative damage and the PDGF increased secretion in cultured human endothelial cells. Thromb. Haeomost. 74, 969-973

Dogukan A., Sahin N., Tuzcu M., Juturu V., Orhan C., Onderci M., Komorowski J., Sahin K. (2009): The effects of chromium histidinate on mineral status of serum and tissue in fat-fed and streptozotocin-treated type II diabetic rats. Biol. Trace Elem. Res. 131, 124-132 http://dx.doi.org/10.1007/s12011-009-8351-8

Eaton J. W., Qian M. (2002): Interactions of copper with glycated proteins: possible involvement in the etiology of diabetic neuropathy. Mol. Cell Biochem. 234-235, 135-142 http://dx.doi.org/10.1023/A:1015988817587

Failla M. L., Kiser R. A. (1981): Altered tissue content and cytosol distribution of trace metals in experimental diabetes. J. Nutr. 111, 1900-1909

Failla M. L., Kiser R. A. (1983): Hepatic and renal metabolism of copper and zinc in the diabetic rat. Am. J. Physiol. 244, 115-121

Feng W., Qian Q., Ding W., Chai Z. (2001): Tissue contents and subcellular distribution of chromium and other tracemetals in experimental diabetic rats after intravenous injection of $\mathrm{Cr} 50$-enriched stable isotopic tracer solution. Metabolism 50, 1168-1174 http://dx.doi.org/10.1053/meta.2001.26760

Forbes J. M., Coughlan M. T., Cooper M. E. (2008): Oxidative stress as a major culprit in kidney disease in diabetes. Diabetes $\mathbf{5 7}$, 1446-1454 http://dx.doi.org/10.2337/db08-0057

Gupta S., Kataria M., Gupta P. K., Murganandan S., Yashroy R. C. (2004): Protective role of extracts of neem seeds in diabetes caused by streptozotocin in rats. J. Ethnopharmacol. 90, 185-189 http://dx.doi.org/10.1016/j.jep.2003.09.024

Halliwell B., Gutteridge J. (1999): Free radicals in biology and medicine. Oxford University Press, New York

Heinecke J. W., Rosen H., Chait A. (1984): Iron and copper promote modification of low density lipoprotein by human arterial smooth muscle cells in culture. J. Clin. Invest. 74, 1890-1894 http://dx.doi.org/10.1172/JCI111609

Isbir T., Tamer L., Taylor A., Isbir M. (1994): Zinc, copper and magnesium in insulin-dependent diabetes. Diabetes Res. 26, $41-45$

Johnson W. T., Evans G. W. (1984): Effects of the interrelationship between dietary protein and minerals on tissue content of trace metals in streptozotocin-diabetic rats. J. Nutr. 114, 180-190

Kakkar R., Mantha S. V., Radhi J., Prasad K., Kalra J. (1998): Increased oxidative stress in rat liver and pancreas during progression of streptozotocin-induced diabetes. J. Clin. Sci. 94, 623-632

Kawamura N., Ookawara T., Suzuki K., Konishi K., Mino M., Taniguchi N. (1992): Increased glycated Cu,Zn-superoxide dismutase levels in erythrocytes of patients with insulin-dependent diabetis mellitus. J. Clin. Endocrinol. Metab. 74, 1352-1354 http://dx.doi.org/10.1210/jc.74.6.1352

Lau A. L., Failla M. L. (1984): Urinary excretion of zinc, copper and iron in the streptozotocin-diabetic rat. J. Nutr. 114, 224-233

Lowry O. H., Rosebrough N. J., Farr A. L., Randall R. J. (1951): Protein measurement with Folin phenol reagent. J. Biol. Chem. 193, 265-275

Mohamed A. K., Bierhaus A., Schiekofer S., Tritschler H., Ziegler H., Nawroth P. P. (1999): The role of oxidative stress and NF- 
kappa $\mathrm{B}$ activation in late diabetic complications. Biofactors 10, 157-167 http://dx.doi.org/10.1002/biof.5520100211

Muchová J., Liptáková A., Országhová Z., Garaiová I., Tison P., Cársky J., Duracková Z. (1999): Antioxidant system in polymorphonuclear leukocytes of type 2 diabetes mellitus. Diabet. Med. 16, 74-78 http://dx.doi.org/10.1046/j.1464-5491.1999.00015.x

Niskanen L. K., Salonen J. T., Nyssonen K., Uusitupa M. I. (1995): Plasma lipid peroxidation and hyperglycemia: a connection through hyperinsulinaemia? Diabet. Med. 12, 802-808 http://dx.doi.org/10.1111/j.1464-5491.1995.tb02083.x

Obrosova I. G., Fathallah L., Liu E., Nourooz-Zadeh J. (2003): Early oxidative stress in diabetic kidney: effect of DL-alpha lipoic acid. Free Radic. Biol. Med. 34, 186-195 http://dx.doi.org/10.1016/S0891-5849(02)01195-4

Oteiza P. L., Mackenzie G. G., Verstraeten S. V. (2004): Metals in neurodegeneration: involvement of oxidants and oxidant-sensitive transcription factors. Mol. Aspects Med. 25, 103-115 http://dx.doi.org/10.1016/j.mam.2004.02.012

Ozcelik D., Uzun H. (2009): Copper intoxication; antioxidant defenses and oxidative damage in rat brain. Biol. Trace Elem. Res. 127, 45-52 http://dx.doi.org/10.1007/s12011-008-8219-3

Parmar P., Limson J., Nyokong T., Daya S. (2002): Melatonin protects against copper-mediated free radical damage. J. Pineal Res. 32, 237-242 http://dx.doi.org/10.1034/j.1600-079X.2002.01859.x

Prasad A. S., Bao B., Beck F. W., Kucuk O., Sarkar F. H. (2004): Antioxidant effect of zinc in humans. Free Radic. Biol. Med. 37, 1182-1190 http://dx.doi.org/10.1016/j.freeradbiomed.2004.07.007

Qian M., Liu M., Eaton J. W. (1998): Transition metals bind to glycated proteins forming redox active "glycochelates" implications for the pathogenesis of certain diabetic complications. Biochem. Biophys. Res. Commun. 250, 385-389 http://dx.doi.org/10.1006/bbrc.1998.9326

Ravi K., Ramachandran B., Subramanian S. (2004): Protective effect of Eugenia jambolana seed kernel on tissue antioxidants in streptozotocin induced diabetic rats. Biol. Pharma Bull. 27, 1212-1217 http://dx.doi.org/10.1248/bpb.27.1212

Raz I., Havivi E. (1988): Influence of chronic diabetes on tissue and blood cells status of zinc, copper, and chromium in the rat. Diabetes Res. 7, 19-23

Repetto M. G., Ferrarotti N. F., Boveris A. (2010): The involvement of transition metal ions on iron-dependent lipid peroxidation. Arch. Toxicol. 84, 255-262 http://dx.doi.org/10.1007/s00204-009-0487-y

Simonian M. A., Gevorkian D. M., Mkhitarian V. G. (1987): Quantitative changes in $\mathrm{Cu}, \mathrm{Zn}$-superoxide dismutase and catalase isolated from the liver of alloxan diabetic rats. Biull. Eksp. Biol. Med 103, 306-308 (in Russian)

Song Y., Wang J., Li X. K., Cai L. (2005): Zinc and the diabetic heart. Biometals 18, 325-332 http://dx.doi.org/10.1007/s10534-005-3689-7

Sun Y., Oberley L. W., Li Y. (1988): A simple method for clinical assay of superoxide dismutase. Clin. Chem. 34, 497-500
Thomas M. C., MacIsaac R. J., Tsalamandris C., Jerums G. (2004): Elevated iron indices in patients with diabetes. Diabet. Med. 21, 798-802 http://dx.doi.org/10.1111/j.1464-5491.2004.01196.x

Valko M., Morris H., Cronin M. T. (2005): Metals, toxicity and oxidative stress. Curr. Med. Chem. 12, 1161-1208 http://dx.doi.org/10.2174/0929867053764635

Venkateswaran S., Pari L. (2003): Effect of Coccinia indica levels on antioxidant status in streptozotocin-induced diabetic rats. J. Ethnopharmacol. 84, 163-168 http://dx.doi.org/10.1016/S0378-8741(02)00294-5

Viktorínová A., Toserová E., Krizko M., Duracková Z. (2009): Altered metabolism of copper, zinc, and magnesium is associated with increased levels of glycated hemoglobin in patients with diabetes mellitus. Metabolism 58, 1477-1482 http://dx.doi.org/10.1016/j.metabol.2009.04.035

Walter R. M., Uriu-Hare J. Y., Olin K. L., Oster M. H., Anawalt B. D., Critchfield J. W., Keen C. L. (1991): Copper, zinc, manganese and magnesium status and complications of diabetes mellitus. Diabetes Care 14, 1050-1056 http://dx.doi.org/10.2337/diacare.14.11.1050

Wang J., Song Y., Elsherif L., Song Z., Zhou G., Prabhu S. D., Sari J. T., Cai L. (2006): Cardiac metallothionein induction plays the major role in the prevention of diabetic cardiomyopathy by zinc supplementation. Circulation 113, 544-554 http://dx.doi.org/10.1161/CIRCULATIONAHA.105.537894

Wang Y. H., Cai L. (2006): Diabetes/obesity-related inflammation, cardiac cell death and cardiomyopathy. Zhong Nan Da Xue Xue Bao Yi Xue Ban 31, 814-818 (in Chinese)

Wei W., Liu Q., Tan Y., Liu L., Li X., Cai L. (2009): Oxidative stress, diabetes and diabetic complication. Hemoglobin 33, 370-377 http://dx.doi.org/10.3109/03630260903212175

Wilson J. G., Lindquist J. H., Grambow S. C., Crook E. D., Maher J. F. (2003): Potential role of increased iron stores in diabetes. Am. J. Med. Sci. 325, 332-339 http://dx.doi.org/10.1097/00000441-200306000-00004

Wohaieb S. A., Godin D. V. (1987): Alterations in free radical tissue-defense mechanisms in streptozocin-induced diabetes in rat. Effects of insulin treatment. Diabetes 36, 1014-1018 http://dx.doi.org/10.2337/diabetes.36.9.1014

Yanardag R., Bolkent S., Tabakoglu-Oguz A., Ozsoy-Sacan O. (2003): Effects of Petroselinum crispum extract on pancreatic $\mathrm{B}$ cells and blood glucose of streptozocin-induced diabetic rats. Biol. Pharm. Bull. 26, 1206-1210 http://dx.doi.org/10.1248/bpb.26.1206

Yoshida K., Hirokawa J., Tagami S., Kawakami Y., Urate Y., Kondo T. (1995): Weakened cellular scavenging activity against oxidative stress in diabetes mellitus: regulation of glutathione synthesis and efflux. Diabeteologia 38, 201-210 http://dx.doi.org/10.1007/BF00400095

Zheng Y., Li X. K., Wang Y., Cai L. (2008): The role of zinc, copper and iron in the pathogenesis of diabetes and diabetic complications: therapeutic effects by chelators. Hemoglobin 32, $135-145$ http://dx.doi.org/10.1080/03630260701727077

Received: May 16, 2011

Final version accepted: June 20, 2011 